\begin{tabular}{|c|c|c|}
\hline & $\begin{array}{l}\text { International Journal of Current Research in } \\
\text { Biosciences and Plant Biology }\end{array}$ & \\
\hline & Volume $4 \bullet$ Number 7 (July-2017) • ISSN: 2349-8080 (Online) & \\
\hline $\begin{array}{l}\text { EXCELLENT } \\
\text { PUBLISHERS }\end{array}$ & Journal homepage: $\underline{w w w . i j c r b p . c o m}$ & www.jichpo com \\
\hline
\end{tabular}

\title{
Floristic Composition, Distribution and Dynamic Regeneration of the Forestry Galleries of the Guinean Savannahs of Adamawa Region- Cameroon
}

\author{
Danboya Emmanuel, Tchobsala and Ibrahima Adamou
}

Biodiversity and Sustainable Development Laboratory, Faculty of Sciences, the University of Ngaoundéré, P.O. Box 454 Ngaoundéré, Cameroon

*Corresponding author.

\section{Abstract}

The present research work aims at: i) evaluating the floristic arrangement and the ecological specification of the forestry galleries; ii) examining the structure of those forestry galleries; iii) appraising the regenerating rate in the forestry galleries and iv) examining the supply in the forestry gallery species. The strutting ligneous stocktaking were carried out on ten plots of land of $20 \times 20 \mathrm{~m}$ arranged along each forestry gallery. The data collection by EXCELL and XLSTAT software showed out that the ligneous species listed out were merged/grouped together in 68 species and 26 families. The Moraceae family presented the highest number of species (09). The Uapaca togoensis is the most abundant species with a relative frequency of $25.63 \%$. The specific highest specific resource is found in the Vina division (38 species) with the Shannon diversity index of 4.25 bits. The structure of the forestry galleries has the "L" shape according to the height of the trees. The medium height of the ligneous species is found in the Mbére division $(51.30 \mathrm{~cm} \pm 17.38)$. The highest regeneration rata is found in the Djerem division $(12.21 \%)$ and the lightest devastating rate is found in the Mayo Banyo division $(20.80 \%)$. The multiple component analysis (MCA) pointed out that grouping. The anemochores are considerable in the Faro and Deo division (69 \pm 28$)$, While the hydrochores in the Mbére Division $(89 \pm 21)$ and the zoochores in the Djerem division $(60 \pm 22)$. The diaspore dispersal strengthens the regeneration of the forestry galleries.
\end{abstract}

\section{Introduction}

The African natural resources develop in an environment that sustains rapid lunges subjected to frantic/frenetic and worrying rate. Uncontrolled forestry ecosystems in this continent gave a new style of a high dynamism in the occupation of and exploitation of the soils. This dynamism manifests itself through the degradation of the forest due to the intensification/ densification of anthropic destruction activities (Tchobsala and Mbolo, 2013). In addition, the high decline in natural resources resulting from this degradation is up-held by many modeling approaches. Besides, they are sharpening the attention of each and everyone who believes on the extinction of the savannah forests or which is transformed into long term 
cultivating areas if the current farming practices remain stable yet, it is accepted by all that the forestry galleries are one of the main privilege sources of the population to meet the ecosystemic demands, namely the high demand in the foot domain, wood used for different purposes and in soil exploitation. The causes of the ecosystem destruction are varied from one locality to the other. Shuku (2009) assess that the destruction of the forestry ecosystem destruction of the forestry ecosystem and above all the forestry galleries because of the numerous causes constituting a group of a complex economical, social and political pressures on which the management of some natural resources lay. Tchotsoua (1996 and 2006), Tchotsoua and Gonné (2009) and Tchobsala (2011) demonstrated that the vegetation of the Adamawa region is highly disrupted and damaged by the local population through of firewood exploitation, voluntary bush fires or slash-and-burn cultivation. Tchotsoua (2006) revealed that forestry galleries have dropped from 1844 to 784 ha between 1951 and 2001; that is covering a reduction of $50 \%$ some forestry galleries related to some Guinean floristic species which are seriously destroyed for farming purpose take up only lower surfaces in the Adamawa savannah. The Adamawa forestry galleries have experienced severe calamities. In the some vain, Moudingo (2007) and Tchobsala et al. (2010) emphasize that the Adamawa region is undergoing serious forestry gallery destruction and the culturing of the structures of the forestry plantations which are the consequences of the clearing for forming areas, for wood exploitation and for services. This region is being badly affected by the drying out or the river silting up, watering places and damps following the deforestation of water banks, forestry galleries and the anarchic handling of the basin sides (Moudingo, 2007). The present research work aims at mastering the floristic composition and the ecological characterization, the structure and regeneration dynamism of the forestry galleries in the high Guinean savannahs of the Adamawa Region-Cameroon.

\section{Materials and methods}

\section{Study area}

The high Guinean savannahs is located between the $4^{\text {th }}$ and $8^{\text {th }}$ at latitude north. Known as the medium-sized plateau higher than $1.100 \mathrm{~m}$ splitter unites by valleys, the Adamawa region is a buffer zone between the SoudanoSahelian savannahs of the North and the humid forest of the south. The plateau is topped by some higher mountains as the Tchabal Mabo $(2,460 \mathrm{~m})$. The study was carried out in three forestry galleries of each division. In all, 15 forestry galleries were used to compile our research work in the Adamawa Region (Moudingo, 2007). The vegetation is essentially made up of savannahs higher as the Adamawa itself (woody savannahs and the dry and clean forests), the lower savannahs of the centre region and east and the Tikar plain (Fig. 1).

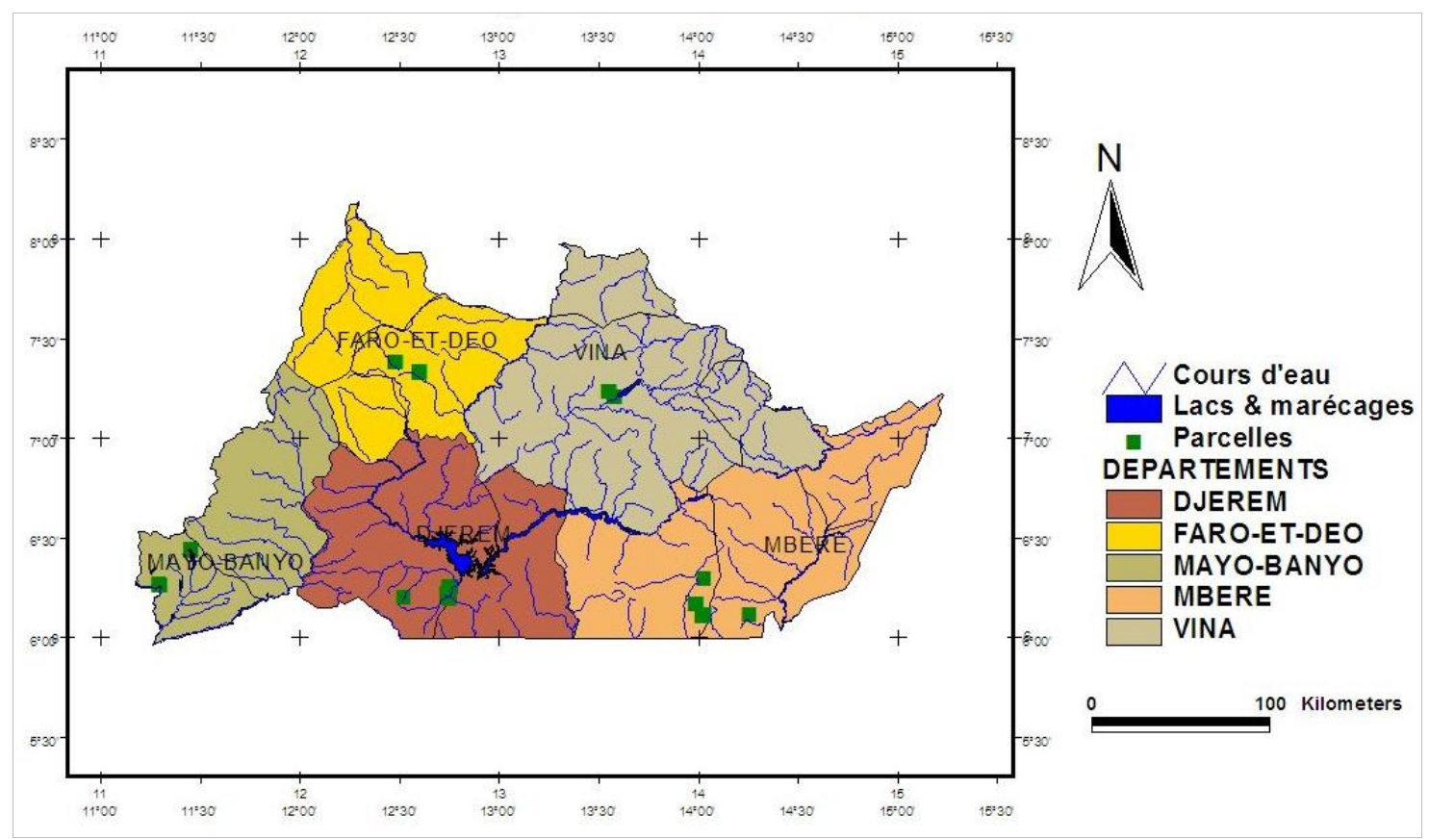

Fig. 1: Localization of the study area: Map of the Adamawa region. 
The transition between the vegetation is possible with a mosaic of plants where grassy and shrub savannahs and forestry galleries alternate. All the ligneous species closest to the area in Ngaoundere are cut down including the forestation area. The vegetation is degraded with the cutting of trees for firewood; fish smoking and pasture. Forestry galleries related to the Guinean floristic species which are seriously over exploited for farming scarcely occupy limited places within the Adamawa savannahs. The latest are highly characterized, on a floristic point of view, by the Daniellia oliveri and the Lophira lanceolata; two unquestionably prolific species and which are on no account favorable to human damages as for as the numerous Andropogonées (Letouzey, 1968).

The shrub savannahs, with higher dominance of species such as the Terminalia sp., Annona senegalensis: The Daniellia oliveri and the Lophira lanceolata (Letouzey, 1968). The vegetation is highly made up of shrubs like the Hymenocardia acida, the Piliostigma thonningii and the Harungana madagascariensis (Tchobsala, 2011). The Adamawa plateau is the water tower of the country. It is from that plateau that the waters source the country (pats in the south and some in the North spring up. Despite strategic importance of the Adamawa waters source some significant erosion problems) of the banks of those rivers and the silting up related to deforestation and overexploitation of the forestry galleries The Adamawa Region map is represented in Fig. 1.

\section{Study method/approach}

For the collection of data related to the floristic composition a canvassing of the research area was done with the help of an aircraft to choose 03 forestry galleries in the five divisions of the Adamawa Region. These forestry galleries have than $80 \mathrm{~m}$ of width and more than $30 \mathrm{~km}$ of length and which have undermined anthropic activities and had priorities in their choice. That is how 15 (fifteen) forestry galleries were selected in the Vina, Djerem, Faro and Mayo Banyo and Mbere divisions (Fig. 2). Ten tassels of $400 \mathrm{~m}^{2}$ each spanningly arranged on two transects were realized on each forestry gallery. All the ligneous species restrained in the tassels were listed. The following parameters were qualified: the height and diameter of the powder puff. The diameter was measured with a wing foot and the height with the help of vague clinometers and with a pole for small trees. In each tassel, cutting stumps and the number of teaps were counted. The diaspores were collected all around the ten main bottom of the experimental fragments. The distance of each diaspore to its pole was assessed.

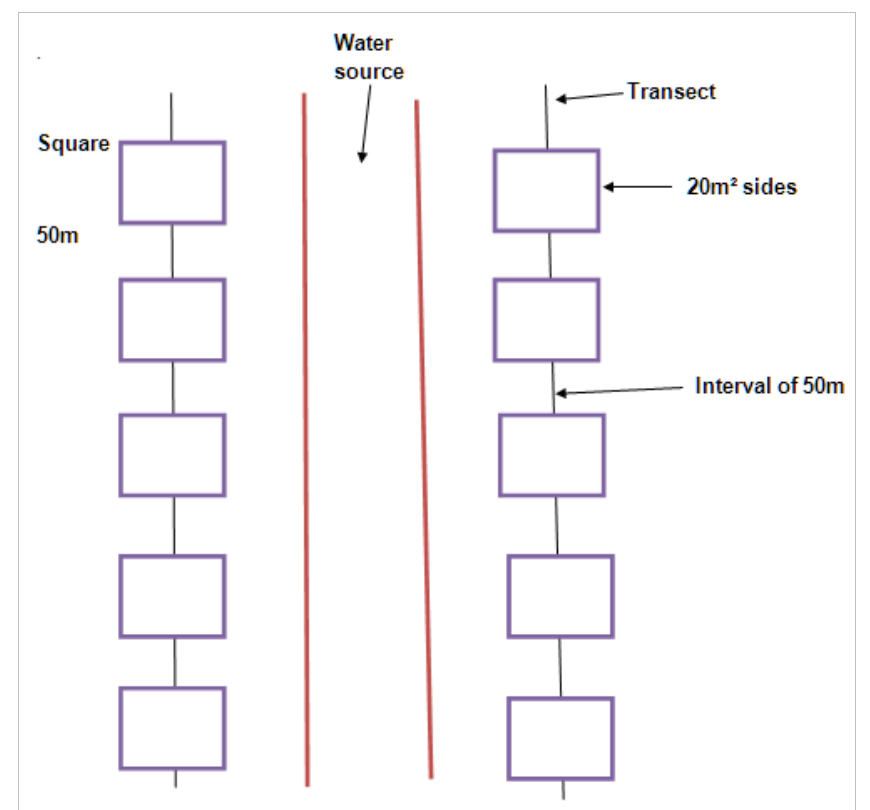

Fig. 2: Arrangement of the placetes in a forestry gallery.

The analyses methods played the role of mediators in the notions of abundance and relative frequency, centesimal frequency, specific contribution, relative collection of mortality and regeneration rates. The relative frequency is the number of subjects of specific species out of the total number of the subjects of the total species, in terms of percentage. $\mathrm{Rf}=(\mathrm{ni} / \mathrm{N}) \times 100$, where $\mathrm{ni}=$ the number of subjects of a species; $\mathrm{N}=$ the total number of subjects of the total species.

The relative collection is the share taken by the top of all the subjects of species on the surface related to the study area. $\mathrm{RR}=\mathrm{Rei} / \mathrm{ST}$, where $\mathrm{Rei}=$ the collection of subjects from a given species and $\mathrm{TS}=$ total surface of the research area.

The mortality rate is the number of subjects died out of the total number of the population. $\mathrm{T}=\mathrm{Nm} / \mathrm{NT}$, where $\mathrm{Nm}=$ number of subjects dead and NT: total number of the population.

The regeneration rate is the number of the leap of the strain and subjects coming from the seeds compared with the total number of the population. TGR = $(\mathrm{NS}+\mathrm{Ng})$ : $\mathrm{Ti}$, where $\mathrm{NS}=$ number of subjects coming from the leap of the strain, $\mathrm{Ng}=$ number of people coming from the seeds and $\mathrm{Ti}=$ total number of people listed. 
The dominance affects the collection of subjects from each species and is represented in percentage. The relative dominance, also known as relative collection is the ratio of the total earth surface (STTe) over the total earth surface of the community (STTe) multiplied by 100.

$$
\mathrm{DR}=\frac{\mathrm{STTe}}{\mathrm{STTC}} \times 100
$$

The relative Curtis value Importance is the total of the relative density, the relative frequency and the relative dominance. IVCR $(\%)=\mathrm{FR}+\mathrm{DR}+$ Der with the IVCR $=$ Curtis importance value; $\mathrm{FR}=$ relative frequency; $\mathrm{DR}=$ relative dominance and Der $=$ Relative density.

\section{The phytogeographic distribution of the species in the forestry galleries}

The first chronological subdivisions in Africa are Engler Work (Lebrum, 1947). Other research works redefined these subdivisions and, among them, are the Lebrun's (1947), Duvigneaud's (1949 and 1953), Monod's (1947) and Aubréville's (1962). Others like White (1979, 1983 and 1986), Denys (1980) focused on the chronological subdivisions in Africa. We opted for the following chronological types: the geographical distribution with broad species are: The cosmopolitans (Cos): species spread all over the world; pantropicals (pan): species peculiar to Africa, America and tropical ASIA; Afro American (AA): species spread out in Africa and tropical, America (pal): species found in Africa and tropical Asia in Madagascar and Australia, Afro Malagasy (AM): species common to the islands of the Malagasy regions and central Africa; Multiregional Africans (PRA): species whose area of distribution covers many African floristic regions where two floristic region are not in contact. The species of Guinean and Soudano-Zambezian links are species whose distribution area spread more or less out neighbouring national regions without manifesting any preference marked out by these regions. They are found within the ecological conditions which are more or less peculiar to each of the regions. In this present case they are species from the Guinean and Soudano-Zambezian regions. The Guinean species are: the Omni or the sub omni guineo Congolais (CG): a species whose distribution area covers Cameroonian the democratic republic of Congo; Occidental Guyenne's (WG): species spread in west Africa and west Cameroon; Cameroon-Congo (Ca-Co): species found in the Cameroon Massif and the Congo
Basin, Cameroon-Gabon (Ca-Gab): species only known in the forestry Massif Cameroon-Gabon-Mayumbe; Cameroon (Cam); Gagab: Species found only in Cameroon.

\section{Community determinations}

The socio-ecological community is set of species, sharing the same and more sociological affinity and characterized by a tendency which tries to assemble in a given biotope; that is within conditions in an established milieu (Duvigneaud, 1974 and 1980). Many authors have tried to speculate on the determination of the ecosociological in tropical areas of Africa (Schnell, 1952; Mullenders, 1954; Mosango, 1990; Sokpon, 1995).

\section{Biological kinds of forestry gallery species}

The biological kind of species is a group of anatomic and morphological system which specifies the vegetative characteristics, its habitat and physiology regardless of both from the systematic position and its capacity for adaptation to the condition in which they live. According to the Raunkiaer ranking (1934) and adapted to the tropical zones by Schnell (1971). There are various biological kinds of species.

The planerophytes (ph) are plats whose growth and arial and persistent sprouting of buds are located at a considerable distance above the soil. They vary corroding to their height as follows:

- The megaphanerophytes $(\mathrm{MgPh})$ : a tree whose height is above $30 \mathrm{~m}$.

- The mesophanerophytes $(\mathrm{MsPh})$ : a tree whose heights wings between $10-30 \mathrm{~m}$.

- The microphanerophytes $(\mathrm{NnPh})$ : a tree whose heights wings $2-10 \mathrm{~m}$.

- The nanophanerophytes $(\mathrm{NnPh})$ : sub-shrubs of 0.4-2m height.

- The volubile climbing phanerophytes (Phgrv);

- The herbaceous climbing phanerophytes (PhGr).

- The epiphytic phanerophytes (PhEp).

The chamephytes (Ch): they are plants whose sprouting buds are aerial but situated at a bow distance under the the soil. They are:

The upright chamephytes (Chd); - the prostrate chamephytes (Chpr); 
The creeping chamephytes (Chrp); - the climbing chamephytes (Chgr)

The geophytes (G): plants whose persistent sprouting buds are housed in the soil during the nasty season. They are: the rhizomateux geophytes (Grh); the tuberous geophytes (Gb); the climbing geophytes (Ggr); the epiphytic geophytes (Gép).

The hemicryptophytes $(\mathbf{H})$ : they are plants whose replacing buds are situated at a low growing soil. They are known as the cespiteux hemycryptohytes (Hce). The theophytes (Th): They are annual plants khoum as non lasting long vegetations devoid as such of sprouting buds and whose life expectancy depends on the seeds. They are. Raised theophytes (Thd); prostrate helophytes (Thpr)- scapeux theophytes (Thsc).

The hydrophytes (Hy): they are aquatic plants whose persistent buds are located at the bottom of water and whose life cycle is only in water.

\section{Diaspore dispersal categories of forestry galleries}

The Diaspore dispersal categories were established thanks to the Dansereau and Lems (1957). The various categories are:

- The pterochores (Ptéro): diaspores which have aliform appendixes.

- The pogonochores (Pogo): diaspores which feathered or silky appendices.

- The sclerochores (scléro): non fleshy and relatively light Diaspores.

- The sarcochores (Sarco): diaspores complexly or partially fleshy.

- The desmochores (Desmo): hanging or adhesive diaspores.

- The ballochores (Ballo): diaspores expelled by the plants themselves.

- The barrochores (Barro): non fleshy, heavy diaspores.

- The pleochores (Pléo): diaspores which have waterline appendix.

The analysis methods equally take into consideration the Shannon diversity index notions, the Pielou equitability indexes as given below. The Shannon diversity index (SDI) was calculated as follows:

$$
\mathrm{SDI}=\sum \mathrm{Ni} / \mathrm{N} \log 2(\mathrm{NI} / \mathrm{N})
$$

Where, $\mathrm{Ni}$ is the enrolment of each species and $\mathrm{N}$ is the enrolment of all the species.

The Pielou equitability index (EQ). It corresponds to the ratio between the scrutinized diversity and the possible maximum diversity of the number of species $\mathrm{N}$. EQ = $\mathrm{SDI} / \log 2 \mathrm{~N}$;

The global density (GD) is the number of the ligneous species per hectare. It is calculated according to the number of the ligneous species listed in each fragment and brought bract per hectare: $\mathrm{GD}=\mathrm{N} / \mathrm{St}$, where, $\mathrm{N}=$ the total number enrolled and $\mathrm{St}=$ global surface.

The earth surface of a ligneous species (STi) depicts the projection area of the represented basis in $\mathrm{m}^{2} / \mathrm{ha}$. It is calculated as follows:

STi $=D^{2} \pi / 4$, where $\mathrm{D}$ is the horizontal medium-sized between the tips of the tassel and $\pi=3.14$.

The EXCELL and XLSTAT software were used for the data collections.

\section{Results}

Composition and floristic diversity of the various forestry galleries in the Adamawa Region

The ligneous species listed in the forestry galleries of the Adamawa region are brought together in 68 plants categories and 26 botanic families. The Moraceae family is among those who have the plant categories (09); immediately followed by the Euphorbiaceae family (06). The highest specific richness is found in the Vina Division (38 species), followed by the Djerem Division (27) and the Mayo Banyo Division (26). The specific richness in Faro et Deo and Mbere Division is relatively less important. It is respectively represented by 20 and 10 species (Table 1). The Mbam and Djerem National parks and some NGOs (WCS, PSFE...) combined efforts of wildlife guards would undoubtedly explain the high specific wealth in the Mbere and Djerem Divisions. In fact, the wildlife quart patrols, motivated by the WSC allow the forestry galleries to benefit from these conservatory efforts. On the other hand, the Djerem Divisions is astride between the virgin forest and the savannah zone and hence, highly brimed with forests and savannah species. The selective and illegal exploitation of rare tree species for many purposes in the Mbere Division could explain the specific low wealth in 
comparison with the other Division. The Shannon diversity index is in the most considerable in the Vina Division (4.25 bits) as well as the Pielou (0.77) equitable index. The Vina division galleries are less anthropised than the galleries in the other divisions for there we are no more resources.

Table 1. Specific richness, the Adamawa floristic galleries diversity indices.

\begin{tabular}{llll}
\hline Divisions & $\begin{array}{l}\text { Specific } \\
\text { richness }\end{array}$ & $\begin{array}{l}\text { Shannon } \\
\text { index }\end{array}$ & $\begin{array}{l}\text { Pielou's } \\
\text { equitability }\end{array}$ \\
\hline Vina & 35 & 4.25 & 0.77 \\
Faro and Deo & 20 & 2.43 & 0.44 \\
Mbere & 10 & 1.22 & 0.22 \\
Djerem & 27 & 3.28 & 0.60 \\
Mayo Banyo & 26 & 3.16 & 0.57 \\
\hline
\end{tabular}

\section{Ecological specification and adjustment of species in the forestry galleries}

Table 2 shows that, in the Vina Division, the most important species is the Syzygium guineense var. guineense (1.32\%) and the most dominant species is the Ficus exasperata $\left(86.08 \mathrm{~m}^{2} / \mathrm{ha}\right)$. In the Faro and Deo division the most important species is the Ficus glumosa $\left(127 \mathrm{~m}^{2} / \mathrm{ha}\right)$ in the Djerem Division the Uapaca togoensis is the most important species (24.4\%) as well as dominant $\left(1941 \mathrm{~m}^{2} / \mathrm{ha}\right)$. In the Mbere Division the Triplochyon excleroxylon is the most important species $(10 \%)$ as well as the most dominant $\left(701 \mathrm{~m}^{2} / \mathrm{ha}\right)$ in the same picture it is evident that the highest aerial collection is found in the forestry galleries of the Djerem Division with $\left(3824.91 \mathrm{~m}^{2} / \mathrm{ha}\right)$; immediately followed by that of the Vina Division $\left(1351.01 \mathrm{~m}^{2} / \mathrm{ha}\right)$ and that of the Mbere Division $\left(1246.97 \mathrm{~m}^{2} / \mathrm{ha}\right)$. Table 2 shows that the most important species found in the Adamawa forestry galleries. The Uapaca togoensis with a relative frequency of $25.63 \%$, immediately followed by the Triplochyton scleroxylon with $11.77 \%$. However, it is important to emphasize that this species is more concentrated on the forestry galleries of the Djerem Division and covers $24.42 \%$ ligneous species collected out of the forestry galleries of the whole region. This species does not exist in the Vina and Mbere Divisions. The highest regeneration ratio, the Uapaca togoensis could explain the highest representative Forestry galleries of the Djerem Division in particular and that of the Adamawa Region in general. In the Vina Division the most represented species is the Syzygium guineense with a relative frequency of $04.07 \%$ in all the Adamawa Region closely followed by the Ficus glumosa with $1.21 \%$. The Tectona grandis is the most important species in the Faro et Deo with $2.86 \%$ and followed by the Ficus glumosa (2.09\%). In those two divisions the savannah types of these species are the most dominant. This could be explained by the fact that, geographically, they are situated in the northern part of the Adamawa Region, juxtaposed to the northern region which is a shrub savannah area. The Uapaca togoensis is abundant in the Djerem Division (24.42\%) and in the Mbere and Mayo Banyo divisions the Triplochyton excleroxylon is the most represented species with a relative frequency of $10.01 \%$ and $1.76 \%$ respectively. Those divisions are situated in the southern part of the Adamawa Region and juxtaposed with the forestry regions of Cameroon (the East and Center Regions). Three species have important percentages with regard to the Curtis Ecological theory. They are: the Vitex chrysocarpa (45.4\%), the Uapaca togoensis $(35.26 \%)$ and the Uapaca guineensis $(31.42 \%)$. These species take over all the others of the forestry galleries of the Adamawa Region.

Table 2. Relative frequency, relative density, relative earth surface and relative Curtis importance value (IVC) (\%).

\begin{tabular}{lllll}
\hline Plant species & Relative frequency & Relative density & Relative earth surface & IVC \\
\hline Vitex chrysocarpa & 0.44 & 24.91 & 20.05 & 45.4 \\
Uapaca togoensis & 25.63 & 3.99 & 5.64 & 35.26 \\
Uapaca guineensis & 4.96 & 9.84 & 16.62 & 31.42 \\
Triplochyton scleroxylon & 11.77 & 0.45 & 1.11 & 13.33 \\
Morelia senegalensis & 0.11 & 4.44 & 8.15 & 12.7 \\
Ficus glumosa & 4.73 & 3.42 & 4.23 & 12.38 \\
Tectona grandis & 2.86 & 4.72 & 3.77 & 11.35 \\
Syzygium guineense var. guineense & 6.16 & 1.02 & 0.63 & 7.81 \\
Entandrophragma cylindricum & 1.32 & 5.58 & 0.73 & 7.63 \\
Ricinodendron heudelotii & 0.33 & 2.68 & 4.49 & 7.50 \\
Canarium schweinfurthii & 0.88 & 3 & 3.31 & 7.19 \\
Pericopsis laxiflora & 0.11 & 4.26 & 1.88 & 6.25 \\
Albizia zygia & 2.75 & 1.66 & 1.52 & 5.93 \\
\hline
\end{tabular}




\begin{tabular}{|c|c|c|c|c|}
\hline Plant species & Relative frequency & Relative density & Relative earth surface & IVC \\
\hline Trilepisium madagascariensis & 0.55 & 1.58 & 3.62 & 5.75 \\
\hline Milicia excelsa & 4.73 & 0.36 & 0.16 & 5.25 \\
\hline Ficus asperifolia & 1.98 & 1.54 & 1.38 & 4.90 \\
\hline Terminalia albida & 0.11 & 1.67 & 3.02 & 4.80 \\
\hline Hymenocardia acida & 2.86 & 1.02 & 0.89 & 4.77 \\
\hline Dialium guineense & 1.65 & 1.64 & 0.97 & 4.26 \\
\hline Lovoa trichilioides & 0.77 & 1.27 & 2.17 & 4.21 \\
\hline Ficus glumosa & 2.2 & 0.97 & 0.77 & 3.94 \\
\hline Parkia biglobosa & 1.32 & 1.86 & 0.73 & 3.91 \\
\hline Harungana madagascariensis & 1.65 & 0.82 & 1.38 & 3.85 \\
\hline Zanthoxylum zanthoxyloides & 2.53 & 0.5 & 0.76 & 3.79 \\
\hline Khaya grandiflora & 0.88 & 0.73 & 1.86 & 3.47 \\
\hline Berlinia grandiflora & 0.88 & 1.13 & 1.31 & 3.32 \\
\hline Trichilia welwitschii & 2.09 & 0.41 & 0.44 & 2.94 \\
\hline Anogeissus leiocarpus & 0.11 & 2.35 & 0.12 & 2.58 \\
\hline Daniellia oliveri & 0.66 & 0.85 & 0.98 & 2.49 \\
\hline Ficus abutilifolia & 0.99 & 0.43 & 0.88 & 2.30 \\
\hline Pycnanthus angolensis & 1.76 & 0.46 & 0.04 & 2.26 \\
\hline Maranthes kerstingii & 0.44 & 1.06 & 0.71 & 2.21 \\
\hline Saba comorensis & 0.11 & 0.87 & 1.17 & 2.15 \\
\hline Afzelia africana & 0.11 & 1.27 & 0.28 & 1.66 \\
\hline Mangifera indica & 0.22 & 0.96 & 0.29 & 1.47 \\
\hline Vitex doniana & 0.66 & 0.56 & 0.14 & 1.36 \\
\hline Gmelina arborea & 0.66 & 0.3 & 0.39 & 1.35 \\
\hline Ochna schweinfurthiana & 0.22 & 0.32 & 0.62 & 1.16 \\
\hline Crossopteryx febrifuga & 0.55 & 0.36 & 0.22 & 1.13 \\
\hline Terminalia mollis & 0.11 & 0.58 & 0.4 & 1.09 \\
\hline Erythrophleum suaveolens & 0.22 & 0.73 & 0.07 & 1.02 \\
\hline Fcus dicranostyla & 0.44 & 0.1 & 0.45 & 0.99 \\
\hline Margaritaria discoides & 0.77 & 0.16 & 0.06 & 0.99 \\
\hline Trichilia emetica & 0.66 & 0.27 & 0.01 & 0.94 \\
\hline Ficus exasperata & 0.11 & 0.65 & 0.06 & 0.82 \\
\hline Malacantha alnifolia & 0.44 & 0.19 & 0.14 & 0.77 \\
\hline Terminalia laxiflora & 0.66 & 0.04 & 0.04 & 0.74 \\
\hline Albizia malacophylla & 0.22 & 0.41 & 0.1 & 0.73 \\
\hline Aphania senegalensis & 0.33 & 0.11 & 0.25 & 0.69 \\
\hline Bridelia micrantha & 0.44 & 0.15 & 0.09 & 0.68 \\
\hline Lophira alata & 0.33 & 0.11 & 0.19 & 0.63 \\
\hline Pachystela pobeguiniana & 0.55 & 0.05 & 0.02 & 0.62 \\
\hline Olax subscorpioides & 0.22 & 0.33 & 0.05 & 0.60 \\
\hline Piliostigma thonningii & 0.44 & 00.1 & 0.03 & 0.57 \\
\hline Musanga cecropioides & 0.44 & 0.03 & 0.05 & 0.52 \\
\hline Santaloides afzelii & 0.22 & 0.16 & 0.13 & 0.51 \\
\hline Ficus polita & 0.11 & 00.2 & 0.12 & 0.43 \\
\hline Lophira lanceolata & 0.11 & 0.08 & 0.23 & 0.42 \\
\hline Synsepalum cerasiferum & 0.11 & 0.19 & 0.02 & 0.32 \\
\hline Picnathus angolensis & 0.11 & 0.06 & 0.04 & 0.21 \\
\hline Terminalia glaucescens & 0.11 & 0.03 & 0.01 & 0.15 \\
\hline Annona senegalensis & 0.11 & 0.01 & 0.01 & 0.13 \\
\hline Total & 100 & 100 & 100 & 300 \\
\hline
\end{tabular}




\section{Vegetation structure of the forestry galleries of the Adamawa Region}

The medium height of the trees is higher in the Mbere Division in the other divisions at the threshlold of $0.5 \%$. It is $51.30 \pm 17.83 \mathrm{~m}$ as shown in Table 3 , this can be explained by the excess in the forestry species. In fact, the Triplochyton scleroxylon, which is a tree of a considerable height with significant diameter, represents $76 \%$ out of the listed species in the division and $10.01 \%$ of all the listed species of all the regions. There is no significant difference at the threshold of $0.05 \%$ between the medium heights of the species in the Mbere Division $(51.30 \pm 17.83 \mathrm{~m})$ and the species found in the Djerem Division $(47.81 \pm 16.46 \mathrm{~m})$. This can be explained by the fact that the forests are more dominant than the savannah.

Among the Mbere and Djerem Division on the other hand and the Vina, Mayo Banyo and Faro and Deo on the other hand there is a significant difference at the same $0.05 \%$ threshold. Between the Mayo Banyo on the one hand and those of the Vina and the Faro and Deo Division on the other hand there is also a significant difference among the medium diameters whose threshold is $0.05 \%$. However, there is no significant difference at the level of the $0.05 \%$ threshold compared to medium height of the ligneous species in the ligneous species in the Vina and Faro and Deo Divisions. This can be explained by the fact that these divisions are mostly constituted of the Guinean savannahs whose tendencies are mostly constituted of the Guinean savannahs whose tendencies are more savanicol than Forested. The radius of the diameters is more considerable in the Mbere and Djerem Divisions which are respectively represented by $45.60 \pm 23.81 \mathrm{~m}$ and $40.25 \pm 15.12 \mathrm{~m}$ ratios. There is no significant difference between the diameter ratios of $0.05 \%$ in these two Divisions. Yet, there is a significant difference in the ratios between these two divisions and the others, namely: The Vina, the Faro and Deo and the Mayo Banyo. There is also a significant difference the diameter ratios of the Vina ligneous species in the Mayo Banyo Division and as far as those of the Vina and the Faro and Deo Divisions. However, there is no significant difference to the $0.05 \%$ threshold as compared with the diameter ratios of the density is more significant in the Mbere Division (201 stems/ha) and less important in the Faro Deo Division (75 stems/ha).

Table 3. Table 3. Heights, diameters and densities of species in the forestry galleries.

\begin{tabular}{llll}
\hline Divisions & Medium height $(\mathbf{m})$ & Medium diameter(m) & Densities (stems/ha) \\
\hline Vina & $16.85 \pm 7.02$ & $23.86 \pm 14.89$ & 80 \\
Faro and Deo & $19.90 \pm 17.83$ & $32.47 \pm 7.94$ & 75 \\
Mbere & $51.30 \pm 17.83$ & $40.25 \pm 15.12$ & 201 \\
Dejerem & $47.81 \pm 16.46$ & $45.60 \pm 23.81$ & 190 \\
Mayo Banyo & $28.38 \pm 16.20$ & $33.46 \pm 18.83$ & 132 \\
\hline
\end{tabular}

\section{Distribution of species in the forestry galleries}

The analysis through multiple components of areas and illustrated species on Fig. 3 clearly shows that there are five different groupings which could correspond to the five divisions of the Adamawa Region. This analysis show that there are differences in related to the species and the different areas of the five divisions; the forestry galleries of each division could have and whose peculiarities as regards to the two qualitative variables could be adopted.

On the vertical position the combination of the two factorial analyses is $42.57 \%$ which is considerably in fervor to $80 \%$; meaning that the difference is spring among the population listed on corridor. A detailed analysis chart helps to identify the corresponding divisions to those populations. These divisions are: the Vina, the Mayo Banyo and the Faro and Deo. The connections between these divisions were revealed in the previous results encountered and helped to describe the galleries these divisions compared to galleries with savinicol qualities. On the horizontal domain the combination of the two factorials is $21.19 \%$, more significantly inferior to $80 \%$ and show that there exist only less meaningful differences among the populations living ground the corridor. The analysis of the species on the charts allows identifying the corresponding divisions to those populations. They are the Mbere and Djerem Divisions. 


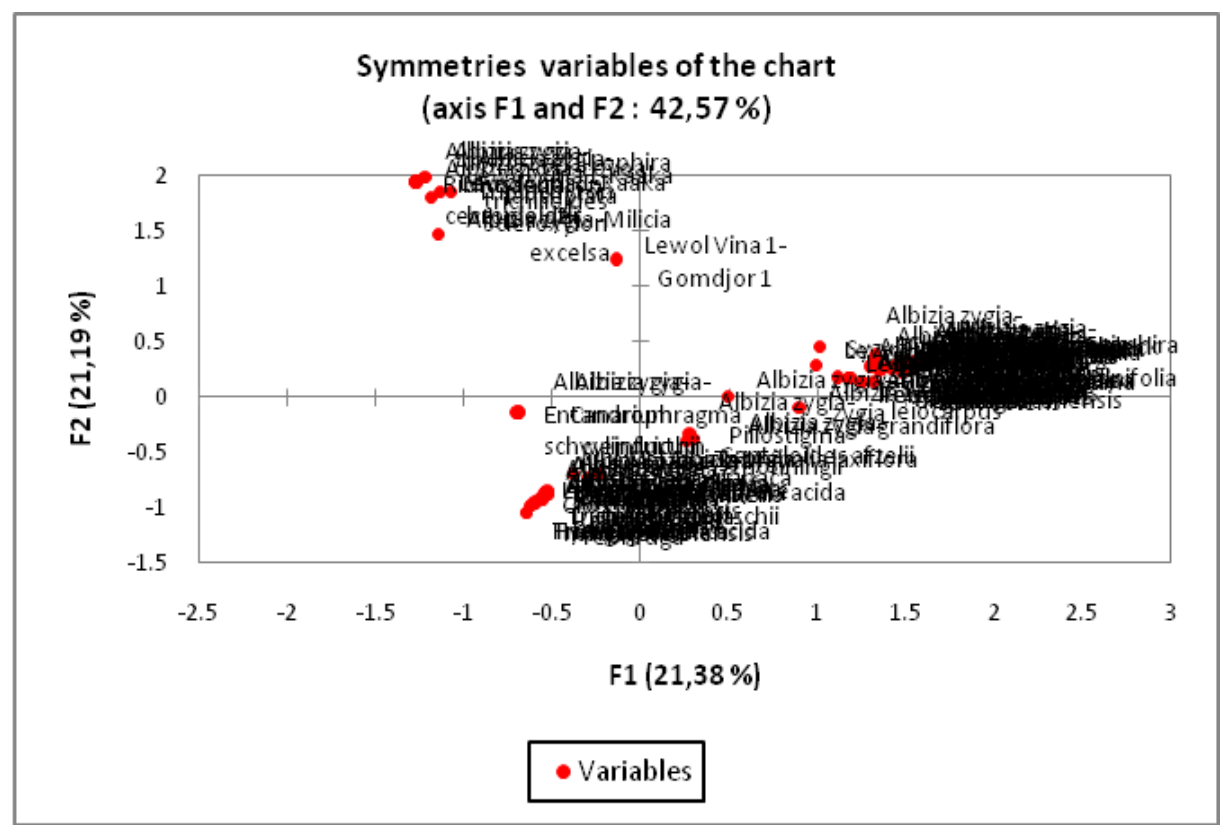

Fig. 3: Multiple component analysis of the density of species in the forestry galleries.

\section{Dispersal dynamism of the diaspores in the forestry galleries}

From Table 4 it comes out that three diaspores were examined; namely: the anemochores, the hydrochores, and the zoochores. The analysis of the medium diaspores variances with a threshold of $\mathrm{x}=0.05$ shows that anemochores ratios is more appreciated in the Faro and Deo Divisions $(69 \pm 28 \%)$. This anemochory which is more considered could be due to the violent speed of the wind in comparison with the other divisions. The hydrochory is more considered in the Mbere Divisions $(89 \pm 21 \%)$ thanks to the concentrated network of the watercourses in its valley. The zoochores high are more considered in the Djerem Division and can be explained by the high presence of wildlife species in the Mbam and Djerem National park. The medium desistance of the anemochore disseminations compared with the mother foot is the highest in the Faro and Deo Division $(13.7 \pm 8.05 \mathrm{~m})$. The wind relatively high speed carries to long distances some Diasporas from the original three. The hydrochore medium distance disseminations in the Djerem Division is the highest $(17.2 \pm 3.34 \%)$ whereas those of the Zoochories are the highest in the Mbere Division $(12.12 \pm 5.50 \%)$. The highest presence of the hydrochory in the Djerem Divisions could be explained by the presence of watercourses which have lot tributaries, no table the Mbam and the Djerem watercourses. The presence of the Djerem Park could explain the fact that the Zachary night be the highest dissemination mean of the diaspores in the forestry galleries of the Djerem Division.

Table 4. Diaspore dispersals in the forestry galleries of the Adamawa Region.

\begin{tabular}{lllllll}
\hline \multirow{2}{*}{ Divisions } & \multicolumn{2}{l}{ Diaspore ratios } & \multicolumn{3}{c}{ Transport medium distance of the diasporas/mother feet (m) } \\
\cline { 2 - 7 } & Anemochores & Hydrochore & Zoochores & Anemochores & Hydrochores & Zoochores \\
\hline Mayo Banyo & $46 \pm 10$ & $25 \pm 6$ & $30 \pm 7$ & $10.02 \pm 3.5$ & $12.21 \pm 65$ & $7.36 \pm 5.2$ \\
Vina & $51 \pm 25$ & $35 \pm 13$ & $48 \pm 13$ & $12 \pm 5.5$ & $8.04 \pm 4.13$ & $6.16 \pm 3.3$ \\
Faro and Deo & $69 \pm 28$ & $62 \pm 15$ & $30 \pm 14$ & $13.7 \pm 8.05$ & $13.31 \pm 5.6$ & $5.14 \pm 4.52$ \\
Djerem & $46 \pm 18$ & $72 \pm 24$ & $60 \pm 22$ & $6.3 \pm 2.5$ & $17.2 \pm 3.34$ & $10.22 \pm 4.20$ \\
Mbere & $45 \pm 16$ & $89 \pm 21$ & $51 \pm 6$ & $4.55 \pm 2.01$ & $8.25 \pm 4.50$ & $12.12 \pm 5.50$ \\
\hline
\end{tabular}

\section{Biological types of species in the forestry galleries}

The biological types of species show that there are more megaphanerophytes of the first rank in the Djerem

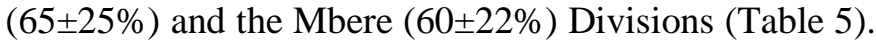

This could be explained by the affluence of the species in the forestry areas of the two divisions. The microphanerophytes are more considered in the Faro and Deo $(64 \pm 24 \%)$ and the Vina $(56 \pm 11 \%)$ divisions because of the affluence of these species in these two 
regions. In addition, the firewood depletion in those divisions does not give any opportunity to the megaphanerophytes to develop themselves in the forestry galleries. That is one of the situations which corrupt the surface of the forestry galleries structuring in those two divisions and especially the Faro and Deo Division. The nanophanerophytes are more considerable in the forestry galleries of the Djerem Division $(86 \pm 32 \%)$, closely followed by the Mbere Division $(52 \pm 15 \%)$ because of the higher representatively of the nanophanerophytes through the germination high rate in the alone divisions and compared to the other divisions. The climbing phanerophytes are more visible in the Mbere $(40 \pm 17 \%)$ and the Djerem $(35 \pm 12 \%)$ divisions. The fact that those two divisions have significant forestry galleries could explain these high rates above, the winding of the creeper of the megaphanerophytes at the detriment of the herbaceous strata of the undergrowth. The epiphytic phanerophytes are more visible in the Faro and Deo $(45 \pm 15 \%)$ and the Mayo Banyo $(35 \pm 12 \%)$ divisions. The collection, less relatively important related to certain divisions could facilitative the movements of insects and birds transporting the spores and seeds of the epiphytic phanerophytes from one ligneous species to the other.

Table 5. Biological varieties of plant species in terms of percentage (\%).

\begin{tabular}{lllllll}
\hline Divisions & MgPh & MsPh & MiPh & NnPh & CIPh & PhEp \\
\hline Mayo Banyo & $40 \pm 15$ & $45 \pm 10$ & $44 \pm 14$ & $25 \pm 6$ & $28 \pm 8$ & $35 \pm 12$ \\
Vina & $20 \pm 8$ & $24 \pm 8$ & $56 \pm 11$ & $22 \pm 5$ & $10 \pm 4$ & $22 \pm 10$ \\
Faro and Deo & $25 \pm 10$ & $20 \pm 11$ & $64 \pm 24$ & $44 \pm 18$ & $15 \pm 7$ & $45 \pm 15$ \\
Djerem & $65 \pm 25$ & $55 \pm 18$ & $30 \pm 13$ & $89 \pm 32$ & $35 \pm 12$ & $25 \pm 15$ \\
Mbere & $60 \pm 22$ & $70 \pm 28$ & $35 \pm 9$ & $52 \pm 15$ & $40 \pm 17$ & $28 \pm 11$ \\
\hline
\end{tabular}

MgPh: Megaphanerophytes; MsPh: Mesophanerophytes; MiPh: Microphanerophytes; NnPh: Nanophanerophytes; ClPh:

Climbing phanerophytes; PhEp: Epiphytic phanerophytes.

\section{Phytogeographical distribution of the forestry gallery species}

It comes out with table 6 that the Djerem and Mbere Divisions have dominant Guinean species. In fact, the sub-omniguineo-congolese species (CG) are more represented in the Djerem (10.33\%) and the Mbere $(8.45 \%)$ divisions. In the Vina and the Faro and Deo divisions the actively present species are found in the Cameroon massif and the congolese basin and are more respectively represented by $3.30 \%$ and $3.33 \%$. The species specifically known in the forestry massif Cameroon-Gabon Mayumbe (Cagab) are more relatively represented in the Mbere and Djerem Divisions with 4.25\% species found in each division. The species spread in West Africa and West Cameroon is also found in the same divisions, that is to say the Djerem and the Mbere Divisions with respectively $6.51 \%$ and $3.33 \%$ species. The species indicated in Cameroon care only found in the Vina with representative species of $1.1 \%$.

Table 6. The phytogeographical types of plant species in terms of percentage (\%).

\begin{tabular}{llllllll}
\hline \multirow{2}{*}{ Divisions } & \multicolumn{2}{l}{ Phytogeographical species } & & & \\
& CG & CE & CA-CO & Ca-Gab & WG & CAM & TOTAL \\
\hline Mayo Banyo & 5.25 & 1.5 & 3.33 & 1.02 & 3.33 & 0 & 14.43 \\
Vina & 1.2 & 3.33 & 3.33 & 3.3 & 1.07 & 1.1 & 13.33 \\
Faro and Deo & 2.1 & 1.1 & 1.2 & 3.33 & 1.1 & 0 & 8.83 \\
Djerem & 9.3 & 10.33 & 3.33 & 4.25 & 3.33 & 0 & 33.72 \\
Mbere & 10.2 & 8.45 & 3.33 & 4.25 & 3.33 & 0 & 29.56 \\
Total & 28.05 & 24.71 & 14.52 & 16.15 & 15.34 & 1.1 & 99.87 \\
\hline
\end{tabular}

CG: sub ominguineo-congolese; CG: Omni or sub-omniguineo Congolais; Ca-Co: Cameroon-Congo; Ca-Gab: CameroonGabon; WG: Occidental Guyenne's; Cam: Cameroon.

\section{Regeneration dynamism and section species of the forestry galleries}

The highest regeneration rate is dominant in the Djerem Division (12.21\%) immediately followed by the Mbere
Division (10.23\%) (Fig. 4). This highest regeneration rate in the two other divisions could be explained by the fact that farming activities are less important in and around these forestry galleries. In fact, the hydrochory and zoochory which have the highest percentage in 
terms of their section favours there generation polity of the species of the forestry galleries. The lowest regeneration rate is efficient in the Mayo Banyo forestry galleries. This negligible regeneration rate would be due to fact that pastoral activities are dense in the division. In fact, the repetitive transhumance of cattle and the consumption of water by those cattle in the forestry galleries damage the seeds and the strums. However, the Mayo Banyo Divisions is an area where forest destructions is the highest $(28.80 \%)$ in the region, immediately followed by the Djerem Division (27.08\%) and the Mbere Division (23.57\%).

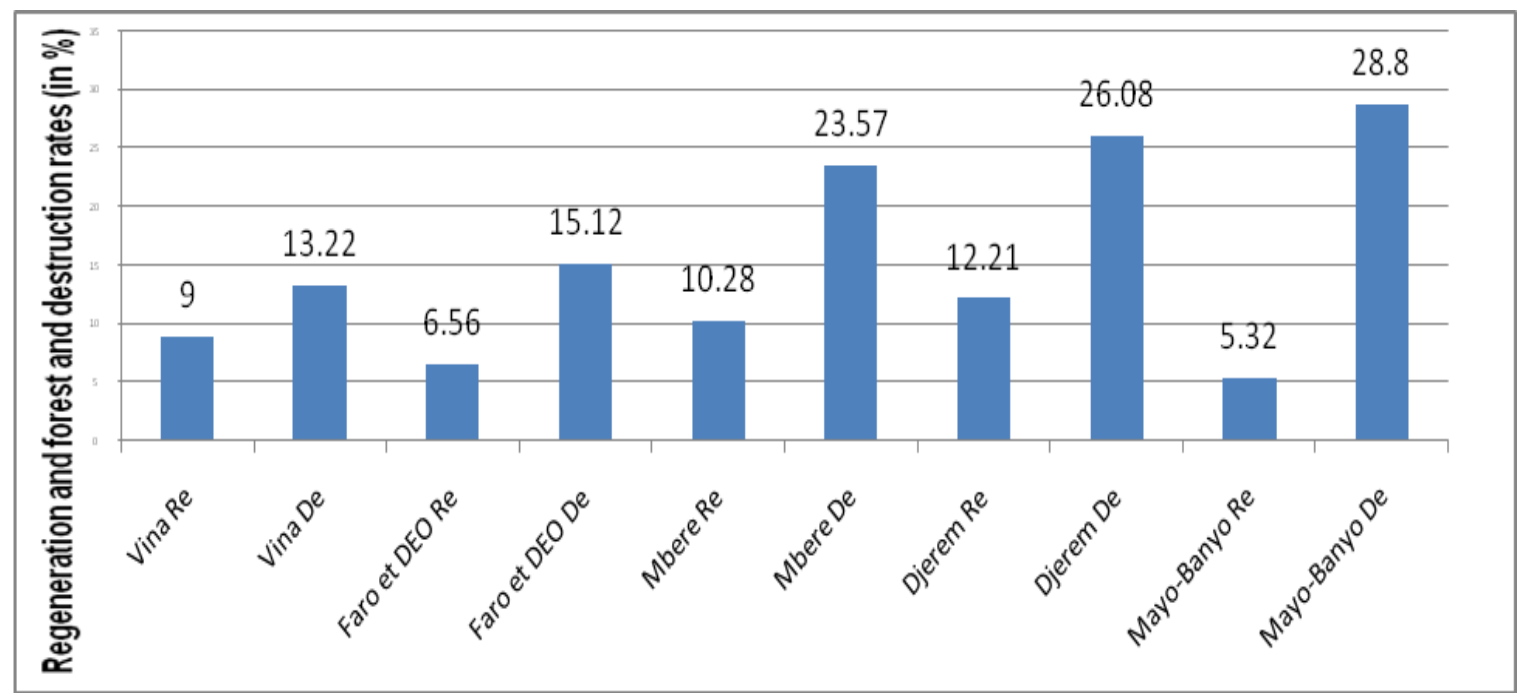

Fig. 4: Regeneration and forest destruction rates. Re: Regeneration in terms of percentage; De: Forest destruction rate in terms of percentage.

\section{Discussion}

\section{Composition and floristic diversities of the forestry and gallery species in the Adamawa Region}

The results of the floristic composition corroborate the Devineau's (1984) theory in the Lamto's forestry galleries ones experienced in Cote d'Ivoire. In fact, he listed 70 species in those forestry galleries sub divided into 38 botanic families. Yet, he denied Belem's theory (1991) who listed 164 plant species in the forestry galleries of the Biosphere wildlife reserve of the Hippopotamus pond in Burkina Faso. This difference could be related to the fact that Belem did the stocktaking in biosphere wildlife be explained by the fact that they are not the same. The floristic composition has shown that the Moraceae are the most diversified in diversities. These results corroborate those of Dourma et al. (2009) in Togo which demonstrated that the tropical forestland the gallery forests of the Guinean savannahs over shadow the Euphorbiaceae and Moraceae species. The floristic diversity in dies obtained from the forestry galleries are the highest as compared to those of Biba (2012) in the pastures of that of that same area and those of Tchobsala et al. (2016a) which are 1.6 bits in the Sahelian area of the Far North Region-Cameroon. Yet, all of them are relatively inappropriate in comparison with the ones experienced by Tchobsala et al. (2016b) who respectively obtained a 4.5 bits of Shannon Index in the shrub savannahs, 4.77 bits in the savannahs planted with trees of the Ngaoundere cliff and 3.77 bits in the non burnt formations in the periurban savannahs of the Ngaoundere town (Tchobsala et al. (2016c).

\section{Adaptation of species in the forestry galleries}

The higher aerial collection noticed in the Djerem Division could be the consequence of the affluence of the Uapaca togoensis with a high top and is generally gregarious in the forestry galleries. In the Vina division the existence of the various species which have medium and dense top could explain its higher aerial collection. These species are generally known as: the Afzelia africana, the Anogeissus leiocarpus, the Syzygium guineense var. guineense and Ficus glumosa species. This result is in contradiction with the Belem (1991) theory in connexion with the hippopotamus pond in the Central African Republic. It is therefore efficient to not that the Afzelia africana is the risk of shepherds because of its highest fodder importance and its appetizing factor by the cattle. In fact, these shepherds lop these species without respecting the norms related to forestry within a 
natural population; that explains the fact that at given moments the top of these trees are generally full of holes. If nothing is being done to protect them they may get extinct in the forestry galleries in the few decades ahead. Actually, this lopping not only interferes the reproductive cycle of the species, but also the shepherd is bound to destroy the trees in their entirety. This situation could tremendously impact the aerial collection of the forestry galleries in that division.

\section{Regeneration and trees cutting down rates}

The high deforestation rate in the Mayo Banyo division (28.80\%) could be explained by the high demand of wood for fabrication of the fence for the cattle and for the delimitation of the pastures. In fact, this division is among those which overuse gate poles for the delimitation of the pasture. That situation could fastly jeopardize the sustainable development of plant resources in this division as compared with the others knowing that plant regeneration recourses is negligible in that division (5.32\%). These results corroborate those of Yonkeu (1993) in the pasture vegetation of that same region (Adamawa). Meanwhile, unlikely to those highlighted by Sandjon et al. (2013) in the MozogoGokoroko National park this ratio could be the consequence of difference between the various types of plants in the region. The effective high presence of the forestry species as well as the two divisions could equally explain the high presence of some effective species only in the forestry massif of the CamerounGabon-Mayumbe (Cagrab); The Megaphanerophytes are present in all the forestry galleries. This result does not abide by that of Samdjon et al. (2013) in the Mozogogokoro National park. This difference is a consequence of various ecosystem species. The dispersal of the Diaspores is effectively possible thanks to the hydrochory and the Zoochory for the forestry galleries are covered all over by watercourses and others are provided a habitat for the wildlife fauna. The extinction of water courses and animals will undoubtedly compromise the evolution and development of forestry galleries in the Adamawa in Region, known as the water tower of Cameroon.

\section{Conclusion}

The research works carried out on the forestry galleries of the Adamawa Region have proved that vegetation formations were drastically damaged by anthropic activities. That high anthropic pressure had negative impacts and the floristic composition, the ecological characterization and the plant regeneration structure and speed. The ligneous species collected were brought together in 68 plants species and 26 botanic subjects. The Moraceae subject has the highest number of plant species (09), immediately followed by the Euphorbiaceae species which has (08) plant species. The most abundant species of the Adamawa forestry galleries, broadly speaking, is the Uapaca togoensis with a relative frequency of $25.63 \%$. The highest regeneration rate is found in the Djerem Division with (12.21\%), immediately followed by the Mbere Division $(10.23 \%)$. The Mayo Banyo Division is the division in which the deforestation rate is the highest with (28.80\%), immediately followed the Djerem (27.08\%) and the Mbere $(23.57 \%)$ divisions. The highest specific wealth is observed the Vina division (38 species), closely followed by the Djerem (27 species) and the Mayo Banyo (26 species) divisions. The multiple element constituent basis of the areas where the species are found clearly shows that there are five different grouping which could associated to the five divisions of the Adamawa Region. This analysis is a clear testimony that there are differences in terms of species found in those areas in the five divisions. The forestry galleries of the Adamawa are brimming with floristic potentialities which are considerable despite the high anthropic pressure made on them. Necessary measures should be taken to successfully handle a research work on the sustainable management of the forestry galleries by following step by step the REDD mechanism for a tremendous reconstitution of the forestry galleries which are being threatened.

\section{Conflict of interest statement}

Authors declare that they have no conflict of interest.

\section{Acknowledgement}

We gratefully thank the University of Ngaoundere and especially the Biological Sciences Department which organized regular Seminars to help us improve on the quality of this document. Our thanks are also extended to the Garoua School of Fauna and Flora labored us with tools for the success of the document and through the US-FISH, US partnership during our second field demonstration. We also thank the local populations of the five (5) divisions of the Adamawa Region for their intense implication for the realization of this project. 


\section{References}

Aubréville, A., 1962. Position chorologique au Gabon, In flore du Gabon Paris, Mus. Nata. Hist. Nat. 3, 311.

Belem, M., 1991. Inventaire floristique des galeries forestières de la réserve de la biosphère de la mare aux Hippopotames. 12p.

Biba, H., 2012. Etat de dégradation et de gestion des ressources pastorales dans les pâturages de la station fourragère de Wakwa, Adamaoua-Cameroun. Mémoire de Master 2. Université de Ngaoundéré. $55 \mathrm{p}$.

Dansereau, P., Lems, K., 1957. The grading of dispersal types in plant communities and their significance. Contr. Inst. Bot. Montreal. 71, 51.

Denys, E., 1980. A tentative phytogeographical division of tropical Africa based on a mathematical analysis of distribution maps. Bull. Jard. Bot. Belg. 50, 465504.

Devineau, J.L., 1984. Structure et dynamique de quelques forêts tropophiles de l'Ouest africain (Côte d'Ivoire), Programme MAB savane. Université d'Abidjan 5: 249p.

Dourma, M., Batawila, K., Wala, K., Kokou, K., Guelly, K.A., Bellefontaine, R., 2009. Régénération naturelle des peuplements à Isoberlinia spp. en zone soudanienne au Togo. Acta Bot. 156, 415-425.

Duvigneaud P., 1949. Le voyage botanique au Congo belge à travers le Bas-Congo, le Kwango, le Kasaï et le Katanga, de Banana à Kasenga. Bull. Soc. Roy. Bot. Belg. 81, 13-33.

Duvigneaud, P., 1953. La flore et la végétation du Congo méridional. Lejeunia 16, 95-124.

Duvigneaud, P., 1974. La synthèse écologique, Populations, Communautés, Ecosystèmes, Biosphère, Paris, Doin. 296p.

Duvigneaud, P., 1980. La synthèse écologique, Populations, Communautés, Ecosystèmes, Biosphère, Noosphère, Paris, Doin. 300p.

Lebrun, J., 1947. La végétation de la plaine alluviale au Sud du lac Edouard. Inst. Parc. Nat. Congo Belge, Exp. Parcs. Nat. Albert, Mission Lebrun (19371938) I: 800.

Letouzey, R., 1968. Etude phytogéographique du Cameroun. Encyclopédie biologique. Paris, Ed. Lechavalier. 511p.

Monod, Th., 1947. Les grandes divisions chrorologiques de l'Afrique, CSA/CCTA, Londres 24: 147p.

Mosango, M., 1990. Contribution à l'élude botanique et biogéographique de l'écosystème forêt en région équatoriale (Ile Kongolo, Zaïre). Thèse de Doctorat, Université Libre de Bruxelles. 446p.

Moudingo, E., 2007. Article sur la situation des forêts au Cameroun. Cameroon Wildlife Conservation Society/ P.O.Box 54 Mouanko- Littoral Province Cameroon. 24p.

Mullenders, W., 1954. La végétation de Kaniama (entre Lubish et Lubilash, Congo belge). Publ. I.N.E.A.C., Sér. Scient. 61: 499p.

Raunkaier, C., 1934. The life forms of plant and statistical plant geography oxford University Press, London. 632p.

Sandjong, S., Mama, N., Adamou, I., Vroumsia, T., 2013. Etude écologique du Parc National de Mozogo-Gokoroko (Cameroun): Prospection préliminaire de la flore ligneuse et du sol pour sa conservation et son amenagement. Int. J. Biol. Chem. Sci. 7(6), 2434-2449.

Schnell, R., 1952. Contribution à l'étude phytosociologique et phytogéographique de l'Afrique occidentale. Les groupements et les unités géobotaniques de la région guinéenne. Mém. IFAN. 18p.

Schnell, R., 1971. Introduction à la phytogéographie des pays intertropicaux. Vol. II: les milieux, les groupements végétaux. Paris, Gauthier-Villars. pp. 503-951.

Shuku, O., 2009. La destruction des écosystèmes forestiers et perte de la biodiversité au bas Congo RDC .Association National Pour l'Evaluation Environnementale. 4p.

Sokpon, N., 1995. Recherches écologiques sur la forêt dense semi-décidue de Pobé au sud-est du Bénin: groupements végétaux, régénération naturelle et chute de litière. Thèse de doctorat, université Libre de Bruxelles. 350p.

Tchobsala, Amougou Akoa, Mbolo Marie, 2010. Impact of wood cuts on the structure and floristic diversity of vegetation in the peri-urban zone of Ngaoundere, Cameroon. J. Ecol. Natural Environ. 2(11), 235-258.

Tchobsala, 2011. Impacts des coupes de bois sur la végétation naturelle de la zone périurbaine de Ngaoundéré (Adamaoua).Thèse de Doctorat. Université de Yaoundé I. 184p.

Tchobsala., Mbolo, M., 2013. Characterization and impact of wood logging on plant formations in Ngaoundéré District, Adamawa Region, Cameroon. J. Ecol. Natural Environ. 5(10), 265-277.

Tchobsala, Djoulaiyatou, D., Ibrahima, A., Souare K., Sofalne, C., 2016a. State, ecological characterization 
and Strategies of sustainable management of plant formations in the Mayo-Kani Division (Far North Region, Cameroon). Int. J. Curr. Res. Biosci. Plant Biol. 3(9), 97-113.

Tchobsala., Ibrahima, A., Dongock, N. D., Nyasiri, J., 2016b. The impact of anthropisation on the floristic composition, the structure and ecological characterization of the Ngaoundéré Cliff, Cameroon. Global J. Sci. Front. Res. Biol. Sci. 16(3), 14-33.

Tchobsala, Ranava, D., Ibrahima, A., Mbolo, M., 2016c. Impact of wood cutting and bush fire on the dynamic of regeneration in the Guinea Savanna of Adamawa Region. Int. J. Curr. Res. Biosci. Plant Biol. 3(9), 114-131.

Tchotsoua, M., 2006. Evolution récente des territoires de l'Adamaoua central: de la spatialisation à l'aide pour un développement maîtrisé. Université d'Orléans. Ecole doctorale sciences de l'homme et de la société. HDR. Discipline (Geographie-
Amenagement-Environnement). 267p.

Tchotsoua, M., Gonné, B., 2009. Des crises socioéconomiques aux crises environnementales sur les hautes terres de l'Adamaoua, Cameroun. Archives ouvertes. CIRAD. 00471335. 10p.

Tchotsoua, M., 1996. L'homme et la dynamique des paysages sur la dorsale de l'Adamaoua. Le Flambouyant no 50, 26-39.

White, F., 1986. La végétation de l'Afrique. Mémoire accompagnant la carte de l'Afrique. UNESCOAETFAT/UNSO (traduction française par P.Bamps). Paris, ORSTOM-UNESCO. 384p.

White, P.S., 1983. The Vegetation of Africa. Natural Resources Research, XX . 356p.

White, P.S., 1979. Pattern, process, and natural disturbance in vegetation. Bot. Rev. 45, 229-299.

Yonkeu, S., 1993. Végétation des pâturages de l'Adamaoua: Ecologie et potentialité pastorale. Thèse de Doctorat. Université de Renne I. 240p.

\section{How to cite this article:}

Emmanuel, D., Tchobsala., Adamou, I., 2017. Floristic composition, distribution and dynamic regeneration of the forestry galleries of the Guinean Savannahs of Adamawa Region-Cameroon. Int. J. Curr. Res. Biosci. Plant Biol. 4(7), 9-22. doi: https://doi.org/10.20546/ijcrbp.2017.407.002 